University of New Orleans

ScholarWorks@UNO

2-1987

\title{
Amongst the Awful Subtexts: Scholes, the Daily Planet, and Freshman Composition
}

Kris Lackey

University of New Orleans, klackey@uno.edu

Follow this and additional works at: https://scholarworks.uno.edu/engl_facpubs

Part of the Rhetoric and Composition Commons

\section{Recommended Citation}

Lackey, Kris. "Amongst the Awful Subtexts: Scholes, the Daily Planet, and Freshman Composition." College Composition and Communication 38.1 (1987): 88-93.

This Article is brought to you for free and open access by the Department of English and Foreign Languages at ScholarWorks@UNO. It has been accepted for inclusion in English Faculty Publications by an authorized administrator of ScholarWorks@UNO. For more information, please contact scholarworks@uno.edu. 


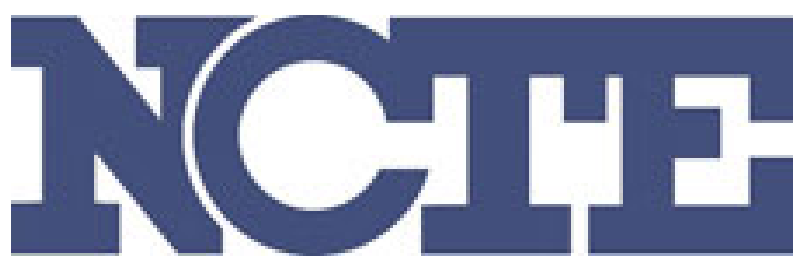

Amongst the Awful Subtexts: Scholes, The Daily Planet, and Freshman Composition Author(s): Kris Lackey

Source: College Composition and Communication, Vol. 38, No. 1 (Feb., 1987), pp. 88-93

Published by: National Council of Teachers of English

Stable URL: http://www.jstor.org/stable/357590

Accessed: 11/04/2011 15:46

Your use of the JSTOR archive indicates your acceptance of JSTOR's Terms and Conditions of Use, available at http://www.jstor.org/page/info/about/policies/terms.jsp. JSTOR's Terms and Conditions of Use provides, in part, that unless you have obtained prior permission, you may not download an entire issue of a journal or multiple copies of articles, and you may use content in the JSTOR archive only for your personal, non-commercial use.

Please contact the publisher regarding any further use of this work. Publisher contact information may be obtained at http://www.jstor.org/action/showPublisher?publisherCode=ncte.

Each copy of any part of a JSTOR transmission must contain the same copyright notice that appears on the screen or printed page of such transmission.

JSTOR is a not-for-profit service that helps scholars, researchers, and students discover, use, and build upon a wide range of content in a trusted digital archive. We use information technology and tools to increase productivity and facilitate new forms of scholarship. For more information about JSTOR, please contact support@jstor.org. 


\title{
Staffroom Interchange
}

\author{
Amongst the Awful Subtexts: Scholes, The Daily Planet, and Freshman Com- \\ position, Kris Lackey, University of New Orleans
}

On a marginally dismal late-autumn morning last year I peeked over the top of my morning paper to watch twenty freshmen reading their morning papers. They are too young to need the habit, but they assume the mandatory posture-a dazed loll-like jaded mid-lifers. We are all reading the same article from the "Dixie Living" section of the Atlanta Journal-Constitution:

\section{That Old Time Mountain Music \\ By Plott Brice}

FAIRVIEW, N.C.-There was something warm and wonderful about the smell of fried chicken at grandma's house on a Sunday afternoon.

That, at first glance, has nothing to do with music. But when the music is Southern, many fetch from the back pockets of their minds the warm, secure memories of times long gone.

When the music is Appalachian Southern, it's a carrousel with visions of yellowish leaves and that first fire of the fall. Apples and apple cider. Saturday nights with friends and family and church on Sunday. And music. Rich, deep and traditional.

Memories like those probably don't get any cornier and, yet, they probably don't get more real, more honest. It's the way it was, and in many cases still is. America, Appalachian style. An island in the South with music, stories and traditions all its own. A region of proud people fiercely loyal to each other and firmly attached to the hand-me-downs of years ago.

And into this corner of America comes David Holt from a home far from the mountains, fretless banjos, hammer dulcimers and the folks who used to go to Sunday meeting "Shank's mare". . . .

Holt [a folk singer] is known across America as the host of Nashville Network's acclaimed television series "Fire on the Mountain." Esquire Magazine says Holt is one of the "register of men and women under 40 who are changing America."

He has traveled all over the world on behalf of the U.S. State Department. The Columbian newspaper El Mundo said of Holt: "He was a better ambassador than the Peace Corps, foreign aid and all the diplomats put together."

Changing America, however, is not exactly what Holt is doing. He's keeping alive an important part of American culture. He's a story teller. . . . (20 Oct. 1985: $1 \mathrm{H}, 4 \mathrm{H})$

We also read that "golf clubs and tennis racquets have not replaced banjos and fiddles 
as the instruments of choice [in southern Appalachia]," that condos may soon line the Appalachian Trail, and that David Holt has appeared on Hee-Haw.

Seasoned detectives of the implied binary opposition by this late-quarter session, the students point out that Brice has built his story on the opposition between two "worlds"- the "Mountain Music World" and the "Outside World." And they supply a boardful of characteristics, to wit:

$\begin{array}{ll}\begin{array}{l}\text { Mountain Music World } \\ \text { traditional }\end{array} & \text { Outside World } \\ \text { nostalgic } & \\ \text { community-oriented } & \\ \text { regional (Southern) } & \text { individual-oriented } \\ \text { insular } & \text { cosmopolitan } \\ \text { tranquil } & \text { busy } \\ \text { uniform in religion } & \\ \text { peaceful } & \text { tumultuous } \\ \text { rural } & \text { urban } \\ \text { wholesome } & \\ \text { static } & \text { changing } \\ \text { primitive } & \text { technologically sophisticated }\end{array}$

Following our usual program, we label these two divisions of content "texts," and give the texts names. I am allowed to name the former, which the students admit to having encountered elsewhere, the Southern Pastoral Text. We would see this text again. In fact, as it appeared in the sports writing, gardening columns, and college catalogues we studied during the quarter, the Southern Pastoral Text became something of a class joke. We call the other the Urban Mess Text.

In the course of fifteen minutes we decide that both texts are prefabricated; that is, Brice's description of Southern Appalachia, what it is and what it is not, comes readymade from countless television shows (The Andy Griffith Show is mentioned), newspaper columns, novels, and, more generally, the Southern pastoral myth. Brice does not, as most of my students would once have assumed, invent his story from scrupulous observation of Appalachian life. Why doesn't he? One student observes that such an approach would necessarily blunt the appeal of the Southern Pastoral Text by introducing unsavory elements of the Appalachian culture. And why does Brice want to avoid doing this? Because it would make David Holt - a man who plays the native music-look bad.

For the remainder of the hour we examine Brice's reliance on other texts as he makes David Holt look good. One such text, which we call the "Contemporary Success Text," catalogues the elements of modern American success, a good many of which may be discovered in Holt's life as created by the journalist: celebrity, good looks, fame, charisma. Holt's natural charm and talents aside, we search the article (our only access to his personality) for the conditions of his success, and we discover, perhaps unsurprisingly, that his fame derives in large part from his association with the Southern Pastoral Text: he thrives by rejuvenating the text through the apparatus of the Urban Mess-electronic broadcast to isolated television watchers. So the Southern Pastoral Text, which is defined partly by its opposition to the Urban Mess Text, predicates the Contemporary Success Text, which is itself partly written by the Urban Mess Text.

But we must take the discussion a bit farther and try to get at the basis of this intricate appeal. What, finally, appeals most forcefully to us in this textual manufacture 
of personality? To answer this question we reflect on our earlier examinations of sports writing and travel writing. In the former we discovered a connection between athletic celebrity and an illusion of regional fame and power; in the latter we found that the allure of travel usually involved a promise that the traveler could wield temporary power (of a sort denied her at home) over her new surroundings. In light of these observations, we search for a center of textual power in "That Old Time Mountain Music."

The young folk singer charms "Dixie Living" readers because he masters the media with a wholesome Southern repertoire, thereby demonstrating the possibility of achieving Contemporary Success without selling out: he accrues the most coveted brand of power not by abandoning Southern Pastoral virtues, but by celebrating them. Thus has the journalist, by skillfully manipulating the texts at his disposal, tapped his readers' desire for a paradigm of unsullied power, rooted in the local.

This introductory pedagogical narrative (tidied, it must be admitted) demonstrates one possible application of the critical program sketched out and theoretically defended by Robert Scholes in Textual Power (New Haven: Yale, 1985). In the early, polemical sections of his brief and accessible book-a sort of structuralist/poststructuralist vulgate-Scholes argues that "In an age of manipulation, when our students are in dire need of critical strength to resist the continuing assaults of all the media, the worst thing we can do is to foster in them an attitude of reverence before texts" (16). Scholes wishes to afford this critical strength through an orderly approach to texts which incorporates fundamental insights from structuralism and deconstruction. In short, such an approach would involve "laying bare" the "binary oppositions which organize the flow of value and power" and then proceeding to "criticize or undo the invidious structure of those oppositions" (4). Though Scholes is here concerned specifically with undoing the textual structure of English teaching as an institution, he extends the program not only to literary texts, but as well to "the supposedly obvious and straightforward productions of journalists, historians, and philosophers" (8). The benefits of dismantling in this fashion, say, a newspaper feature story, lie not only in awakening students to the shaping power of texts they encounter and bring to bear, but also in helping them recognize the interests they share with others of the same social class, academic affiliation, political outlook, or-in the case of our introductory example-region. For criticism, as Scholes points out, "is always made on behalf of a group" (24).

Without a doubt, structuralism and deconstruction suffer some dilution in this pedagogy. In theory, for instance, deconstruction ceases to work whenever it becomes a system: it defies praxis. Yet the subtle and very rigorous examination of "traces" and the idea of writing under erasure, if they are not vulgarized and perverted with good intention, may well remain esoteric activities and yield nothing to a generation of students who might otherwise manage to cultivate a hardy applied skepticism based on the broadest assumptions of deconstruction. If the dislodging of subtexts in a newspaper article seems a factitious and glib m. o. in comparison with Derrida's critique of the metaphorical underpinnings of western philosophy (and so it is), we must mind the constraints of freshman packaging: any critical system must be taught, virtually ex nihilo, in a manner of weeks, from scant and easy paradigms; and any object text must be immediately readable. Under these conditions we can expect at best to leave students with both an awareness of the subtexts operating in even the simplest piece of journalism and a method with which they can parse these subtexts. So however theoretically naive such an approach may be, it affords the freshman English student a measure of informed political sway over the prose of her world.

Some might argue that a freshman course fueled by journalistic texts deprives students of worthy prose models. Such an objection raises the question of what teachers 
commonly make of these models. My own habits suggest that when an essay by $\mathrm{E}$. B. White or E. M. Forster is on the slate, much appreciative commotion is at hand. We set about inculcating some real humility (and counterfeit joy) in the august presence of Imagery, Cadence, Diction, and Tone, all the while removing the text farther and farther from the student's critical ken. In the end, the student has mastered a terminology but forfeited an opportunity to challenge the text, because we have enshrined it. Lest I be accused of creating a false dilemma here, I must note that Textual Power demonstrates the application of structuralist/poststructuralist techniques to works in the literary canon, so the belletristic essay is not itself the culprit. At fault is a notion of "models" that not only blunts self-scrutiny but confirms the student's suspicion that great essayists are, in fact, inimitable. For purposes of imitation, journalistic style offers as many good qualities as can be assimilated by fledgling writers in a few weeks: conciseness, energy afforded by strong verbs, specificity, a strong sense of closure. In sum, a freshman composition course which brings Scholes's program to bear on newspaper stories arms students with a critical method they can apply readily and confidently to prose that has not been glued into a college textbook. Because the text they address comes smudgy from the press, free from the hectoring of officious editors, students sense the immediacy and originality of their work, and I suspect they may be less likely to discard their critical skills when the semester ends.

In the course of a ten-week quarter, during which the students subscribed to the Sunday Atlanta Journal-Constitution, we examined five sections of the paper-Sports, Dixie Living, Comics, Home and Garden, and Travel-as well as an armed forces recruitment brochure, one installment of As the World Turns, and a college catalogue of each student's choice. From each Sunday section in turn, we selected two or three articles for an analysis that turned upon three questions: 1) Who is the implied reader of this article? 2) What are the central binary subtexts, and how can they be dismantled? 3) What is the meaning and purpose of the section of the Sunday paper?

During the week we spent on the Travel section, for example, we first identified the implied readers of several articles: the wealthy sensualist, the impecunious anthropologist, the dauntless thrill-seeker, the insecure foreign-experience collector, and so forth. The identity of the implied reader usually led us to the duelling subtexts. If the article were addressed to the budget-conscious pilgrim of the real folk experience, for instance, we could construct from the author's explicit and implicit disavowals an opposing travel text incorporating the desiderata of the insecure foreign-experience collector. The pilgrim looks to serendipity, thrift, and vulnerability to throw him in with folk life; and, while he may not come out and say so, he scorns the insulating comforts of the group tour, with its schedules, buses and hotels. Having drawn out these binary texts, we could proceed, in the same fashion we did with "That Old Time Mountain Music," to examine the sources of the writer's texts, the writer's identification with a group of people who share his talents and his deprivations, and the sorts of power the writer hopes to wield over his reader and his exotic environment.

Finally, at the conclusion of our Travel week, we surveyed the articles we had read, with an eye toward understanding the rubric itself. One student concluded that travel writers create fictions of fun: they draw from a repertoire of texts to tell their readers what fun is. And what motives are commonly discovered in these texts? Certainly the reader is being plied with exotic fantasies, a number of which found their way to the chalkboard, but the wish travel writers seem to exploit most often is the yearning to assume, provisionally, another identity - to be an imposter for a fortnight. Imposter status appeals to readers because, among other things, it promises to grant them unwonted power over their surroundings. The pilgrim we have spoken of likes very much to play the intrepid anthropologist, for whom the corn dance or pub sing repre- 
sent opportunities to showcase his analytical powers; his enlightened readers might like to do the same. And the travel writer who addresses readers seeking escape from drudgery often keys on role reversal when she commends a resort staff for its merry officiousness. This is enough to suggest how a week's work on a newspaper section (or a soap opera or recruitment brochure) might generate a critical approach to the operations of subtexts, genres, target readers, and class interests.

Composition topics follow easily from such discussions. In accordance with the time-honored progression in subject matter from personal experience to analysis and argument, I first assigned an essay in which students were to choose a model from among the travel articles we read and imitate its conventions as they introduced their target reader to the wonders of their hometowns. In the next essay, written after a discussion of the Home and Garden section, I asked them to assume the persona of a reader who was definitely excluded, because of class and income, as an implied reader of an article on ritzy redecoration. Although for most of these students such a critical point of departure was decidedly artificial, it nonetheless provoked them to adopt an adversarial voice as they took the excluding subtexts to task. Responding to the author's condescending suggestions of ways in which one might include that proletarian enormity - a recliner-among otherwise tasteful great room appointments, one student fired, "It is like he is telling you it's all right to have one if you can afford expensive things to cover it up." And as for the required camouflage, well, "Earning $\$ 125$ a week, I have no money to 'aim for patterns everywhere."

In subsequent assignments I asked students to identify, name, and articulate first individual subtexts, then opposing subtexts. In the following passages, four students are discussing single subtexts they discerned in a recruitment pamphlet of their choosing:

1. The Rush Handbook attempts to make each girl that reads it feel as if a sorority will make her a well-rounded person and thereby build a sense of security. This security subtext is brought to light through character building in social aspects, leadership ability, campus and community service, scholarship, and sisterhood.

2. "Thirty men report to you." The Navy officer therefore must have the responsibility to control and lead thirty men. The piece of literature ties the above fact in with the fact that these thirty men will be in control of millions of dollars worth of equipment.

3. What does "power" mean as a subtext? Basically, a power subtext offers to the reader a sense of power not normally available to her. The power subtext in recruitment literature usually offers the reader a sense of superiority over other people, even though the reader may never achieve actual authority over anyone else. A power subtext might also inform the reader about power over oneself. . . . The manner in which the power subtext is used determines the meaning of the subtext.

4. Another advantage the pamphlet's power text emphasizes is the edge a scientist may gain in the Air Force over his civilian counterparts. The text implies that with [the] modern technology and independent research offered by the Air Force, one may excel beyond others in his field. . . . The power text in this concept is the prospect of having a jump on the competition in the job search following Air Force retirement.

These excerpts capture the vigor and confidence of writers who feel they can go oneon-one with the texts that honey and hawk at them every day. If the analyses are 
system-ridden and heavy-handed, better that than the studiously detached, selfeffacing, and apolitical persona so often encouraged by our own behavior as exegetes of the secular scripture.

The final test of any program lies in its application, and Scholes's program, applied to several forms of popular writing, teaches well. It demands a good deal of time, care, and preparation, because there is no editorial apparatus and the text is always fresh. In the end, these constraints, which you share with your students, prove helpful, for not only do you share your students' anxiety before the opaque text, you also quite often have occasion to appreciate the vastness of your own textual naivete.

\section{Conquering the Myth: Expository Writing and Computer Programming, Nancy Hoar, Western New England College}

Often students majoring in engineering, mathematics, or computer science seem to believe that a person who is proficient in mathematics and the sciences cannot also be proficient in writing. Some students really believe this myth. Some merely use it as a convenient rationalization. In either case, the myth is an obstacle to better writing. What is ironic is that these students are usually computer-literate and will exclaim, "I can write a program, but I can't write a composition."

The truth is: Anyone who can write a computer program has many of the skills needed to write a composition-not necessarily a great composition, but certainly an adequate composition. This is so because computer programs and expository writing are based on similar cognitive principles. And we can help some of our technicallyoriented, computer-literate students write better if we illustrate these five skills of programming and composing in our classes.

First, both programming and expository writing are based on the ability to recognize that a complex whole is composed of manageable parts. Computer programs are commonly composed of subprograms (such as procedures and functions). For example, in a program designed to tally the scores of a weekly bowling league and to determine the winner, there might be four subprograms: one to enter the names and weekly scores, another to tally each player's accumulated scores, a third to sort these scores, and a fourth to print the name and score of the league winner.

A piece of expository writing is also composed of smaller parts. For example, in a short essay comparing middle class American parents with typical parents found in the upland jungles of New Guinea there might also be four parts (paragraphs). There might be an introductory paragraph, a second paragraph comparing the role of the father, a third comparing the role of the mother, a fourth summarizing the entire composition.

A second skill underlying programming and expository writing is the ability to identify the necessary steps for achieving a goal or supporting a generality. The program writer must determine the parts (or subprograms) that are needed and the most efficient ordering of these parts. For example, in the bowling tournament program, there must be a subprogram to print the information, otherwise the desired output will remain electronically and invisibly stored on a disc. Moreover, this subprogram must be effectively ordered so that it follows the subprograms that enter and tally the scores, or else there will be nothing to print. Also, within the scope of each of these subprograms, the programmer must determine the necessary instructions and the required order of these instructions in order to get the job done correctly.

Likewise, the expository writer must determine the optimal ordering of each paragraph to present the composition most effectively. For example, in the composition about parents, the writer must decide whether to discuss the role of the father before 